\title{
OPEN Spatial distribution and potential health risk of fluoride in drinking groundwater sources of Huaibei, Anhui Province
}

\author{
Yunhu $\mathrm{Hu}^{1,3}$, Mu You ${ }^{2,3}$, Guijian Liu ${ }^{3 凶}$ \& Zhongbing Dong ${ }^{4}$
}

Fluoride enrichment in drinking groundwater at Huaibei leads to potential health risk to the residents. A total of $\mathbf{4 9}$ groundwater samples from groundwater sources were collected to evaluate the potential health risk of fluoride ingestion through drinking water for children and adults in Huaibei. Results shown that the average concentration of fluoride in centralized sources is less than that of decentralized sources, which may be attributed to different geological conditions including fluoriderich minerals, environmental conditions and high fluoride waste discharge. The corresponding health risk value of fluoride in centralized source is lower than that in decentralized one, and the $H I$ values of fluoride in the three exposed groups varied in the same order: infants > children > adults. Infants and children were more sensitive receptors to the non-carcinogenic health hazards of fluoride than adults. Special care should be taken to infants and children for the highly prone to health risk compared to adults.

Groundwater is one of the major sources of drinking water specifically in the arid and semi-arid regions on the earth ${ }^{1,2}$. Occurrence of fluoride in groundwater has attracted wide attention in the world due to it closely related to human health ${ }^{3}$. Fluoride is an essential micronutrient to maintain human bone development and growth ${ }^{4}$. Moderate fluoride intake can reduce the incidence rate of dental caries and promote bone development. Insufficient intake will cause incidence rate of dental caries ${ }^{5}$, while the excessive intake will cause endemic fluorosis ${ }^{6,7}$. Many studies show that fluoride content in drinking water is positively correlated with the incidence rate of fluorosis ${ }^{8,9}$. Long-term drinking of high fluoride water can cause maladjustment of calcium and phosphorus metabolism in human body, resulting in calcium deficiency and fluorosis ${ }^{10}$. Fluorosis can also make pregnant women postpartum paralysis ${ }^{11}$. Acute fluorosis can cause serious corrosion of stomach and degeneration of liver and kidney cells, fertility reduction including miscarriage, birth abnormalities and cancer in lungs, bone, bladder and uterus ${ }^{10,12,13}$. Studies have shown that developing children are more sensitive receptors than adults and face higher health risk of fluoride. High concentration of fluoride in drinking water have a negative effect on the children's intelligence quotient (IQ), and dental fluorosis may be the early indicator of children's IQ impairment ${ }^{14,15}$. In view of the above facts, it is of great practical significance to limit the intake of high fluoride for people's health. High fluoride groundwater health implication is a worldwide public health problem, especially in developing countries. It was reported that more than 60 million people are at high risk of fluorosis (dental and skeletal) in northwest China ${ }^{16}$. In order to ensure the safety of drinking water, the guideline fluoride value of $1.5 \mathrm{mg} / \mathrm{L}$ for drinking water was suggested by the World Health Organization ${ }^{17-19}$.

High concentration of fluoride in groundwater is mainly existed in the arid and semi-arid area with high evapotranspiration and low rainfall ${ }^{1,20}$. Elevated fluoride in groundwater is primary originated from lasting water-rock interactions and mineral weathering from fluoride bearing minerals such as fluorit, fluor apatite, biotite and phlogopite ${ }^{9,21,22}$. The concentration and transformation of fluorine in groundwater are determined by various factors, such as hydrogeochemical settings, temperature, $\mathrm{pH}$, solubility of fluoride rich minerals and complexing ions ${ }^{12,23,24}$. In addition, high fluoride groundwater could be related to anthropogenic activities, such as phos-phate fertilizer application, burning of coal, glass and ceramic industry ${ }^{25,26}$. Meanwhile, fluoride could be released from fluoride-containing waste and waste residue by leaching and infiltration of rainfall and

\footnotetext{
${ }^{1}$ School of Chemistry and Materials Engineering, Huainan Normal University, Huainan 232001, China. ${ }^{2}$ School of Bioology Engineering, Huainan Normal University, Huainan 232001, China. ${ }^{3}$ School of Earth and Space Sciences, University of Science and Technology of China, Hefei 230026, China. ${ }^{4}$ School of Earth and Environment, Anhui University of Science and Technology, Huainan 232001, China. ${ }^{\varpi}$ email: Igj@ustc.edu.cn
} 
snowfall, finally resulted in potential soil and groundwater pollution. With the development of economy, the improvement of people's living standards and the strengthening of health awareness, more and more attention has been paid to the health problems related to drinking water. Because the fluoride in drinking groundwater has a direct impact on human health, it is necessary to study the distribution characteristics and influencing factors of fluoride in groundwater, and carry out health risk assessment on the residents, which is of great significance to ensure the safety of drinking water.

Huaibei is located in the arid and semi-arid area. Groundwater is the main water source to ensure its social and economic development ${ }^{27}$. For the high concentration of fluoride in the groundwater of Huaibei City (China), and the prevalence of dental fluorosis is more than $50-90 \%{ }^{28}$. In recent years, the demand for water resources is increasing greatly with the accelerate development of socioeconomic and urbanization. The urban water supply of Huaibei is supplied by tap water. Due to the lack of water purification and other infrastructure in rural areas, some areas still use groundwater with high fluoride content as the main drinking and irrigation water source. Long-term excessive fluoride intake will affect the health of residents. Many studies had focused on the distribution characteristics and quality evaluation of groundwater fluoride in Wanbei Plain ${ }^{27,29-31}$. However, there is no comprehensive and systematic analysis on the distribution and causes of high fluoride water in Huaibei City, and there is no literature on the health risk assessment of fluoride in groundwater. Therefore, the spatial distribution characteristics, influencing factors analysis and health risk assessment of fluoride in Huaibei city provide the basis for the accurate evaluation of groundwater situation in Huaibei City, and have important practical significance for the prevention and control of fluoride disease and urban drinking water safety.

The groundwater system with typical representativeness and can be partitioned into the Quaternary aquifer and the Carboniferous limestone aquifer in Huaibe ${ }^{27}$. And groundwater plays an important role in economic and social development. The analysis of groundwater fluoride distribution characteristics and health risk assessment are of great significance to the protection of groundwater safety and residents' health. The main objectives of this study are to (1) determine the spatial distribution characteristics of fluorine; (2) analysis on influencing factors of fluoride in groundwater; (3) comparison of health risk assessment of fluoride in groundwater between infants, children and adults. The results from this study will provide scientific basis for managers to formulate health promotion strategies and measures, carry out fluorosis prevention and ensure groundwater drinking safety, so as to protect the health of residents.

\section{Materials and methods}

Study area. Huaibei is located in the north of Anhui Province with latitudes of $116^{\circ} 23^{\prime}-117^{\circ} 02^{\prime} \mathrm{E}$ and longitudes of $33^{\circ} 16^{\prime}-34^{\circ} 14^{\prime} \mathrm{N}$, respectively. It governs three districts (Xiangshan District, Duji district and Lieshan District) and one county (Suixi County) with a total area of $2714 \mathrm{~km}^{2}$. Xiangshan mountain lies in the north of Huaibei with a height above sea level of $342 \mathrm{~m}$. The terrain is flat, high in the northwest and low in the southeast. The quaternary sediments are mainly alluvial deposits, followed by alluvial proluvial and slope diluvial deposits. The thickness gradually thickens from north to south, ranging from 10 to $100 \mathrm{~m}$. The main lithology is sub clay, clay, silty fine sand, etc. In the piedmont area, carbonate rocks are buried directly under the quaternary system. The annual average precipitation is $816.7 \mathrm{~mm}$, of which the annual precipitation in July, August and September accounts for $70 \%$.

The groundwater in Huaibei can be divided into karst water in carbonate aquifers and pore water distributed in loose Quaternary sediments. Karst water is mainly composed of Saiwu and Ordovician carbonatite. It is widely distributed and is the main water supply layer of Huaibei. The main recharge sources of groundwater are precipitation infiltration in exposed area of carbonate rock stratum in mountainous area and overflow recharge from overlying pore aquifer in plain area ${ }^{31}$. The main aquifer of pore water is composed of quaternary and neogene unconsolidated aquifer. The thickness is $40-120 \mathrm{~m}$. The groundwater is mainly supplied by precipitation infiltration, and then by the river side. The groundwater resources are sufficient with water output of 100-2000 $\mathrm{m}^{3} /$ day. The quality of shallow groundwater is generally worse than that of deep groundwater in loose Quaternary sediments, which is vulnerable to human activities such as industry and agriculture ${ }^{27}$. As a result, the types of shallow groundwater are complex and with high concentrations of $\mathrm{NO}_{3}{ }^{-}$and total dissolved solids (TDS).

Sample collection and test. A total of 49 groundwater samples were collected (Fig. 1), including 11 karst water samples and 38 pore water samples. The karst water samples were collected from centralized water supply wells in urban areas with the depth from 180 to $260 \mathrm{~m}$, while the pore water samples were collected from decentralized groundwater sources in surrounding villages and towns or enterprises with the depth from 8 to $160 \mathrm{~m}$. Each well was pumped for $10 \mathrm{~min}$ until about twice the volume of the well was discharged, and stable chemical conditions were achieved ${ }^{2}$. The sampling locations were recorded with a global positioning system (GPS) equipment (Garmin Etrex 10) ${ }^{26}$. Temperature, pH, EC, DO and TDS were measured with the water quality field kit (ESICO Model-1160E) in situ. The groundwater was sampled with plastic bottles after thoroughly rinsing with water from the well, acidified to $\mathrm{pH} 2$ and stored at $4{ }^{\circ} \mathrm{C}$ in the refrigerator, all the samples were transported to the Laboratory of Anhui Geological Prospecting Bureau for detection as soon as possible. The concentrations of anions $\left(\mathrm{F}^{-}\right.$and $\mathrm{NO}_{3}{ }^{-}$) were measured by ion chromatography (Dionex, ICS-3000, USA), while cations $\left(\mathrm{Ca}^{2+}, \mathrm{Mg}^{2+}, \mathrm{K}^{+}, \mathrm{Na}^{+}\right)$were analyzed by atomic emission spectrometer (ICP-AES, Perkin Elmer Optima 5300DV, Waltham, Massachusetts, USA). The collection, storage and transportation of groundwater samples are carried out in accordance with the requirements of Regulation for water environmental monitoring (SL219-2013) set by Ministry of Water Resources P.R.C. The accuracy and precision of analyses were measured through spiked samples duplicate samples and analysis of the blanks, the relative standard deviation of determination for major ions measured major anions were within $\pm 5 \%$. 


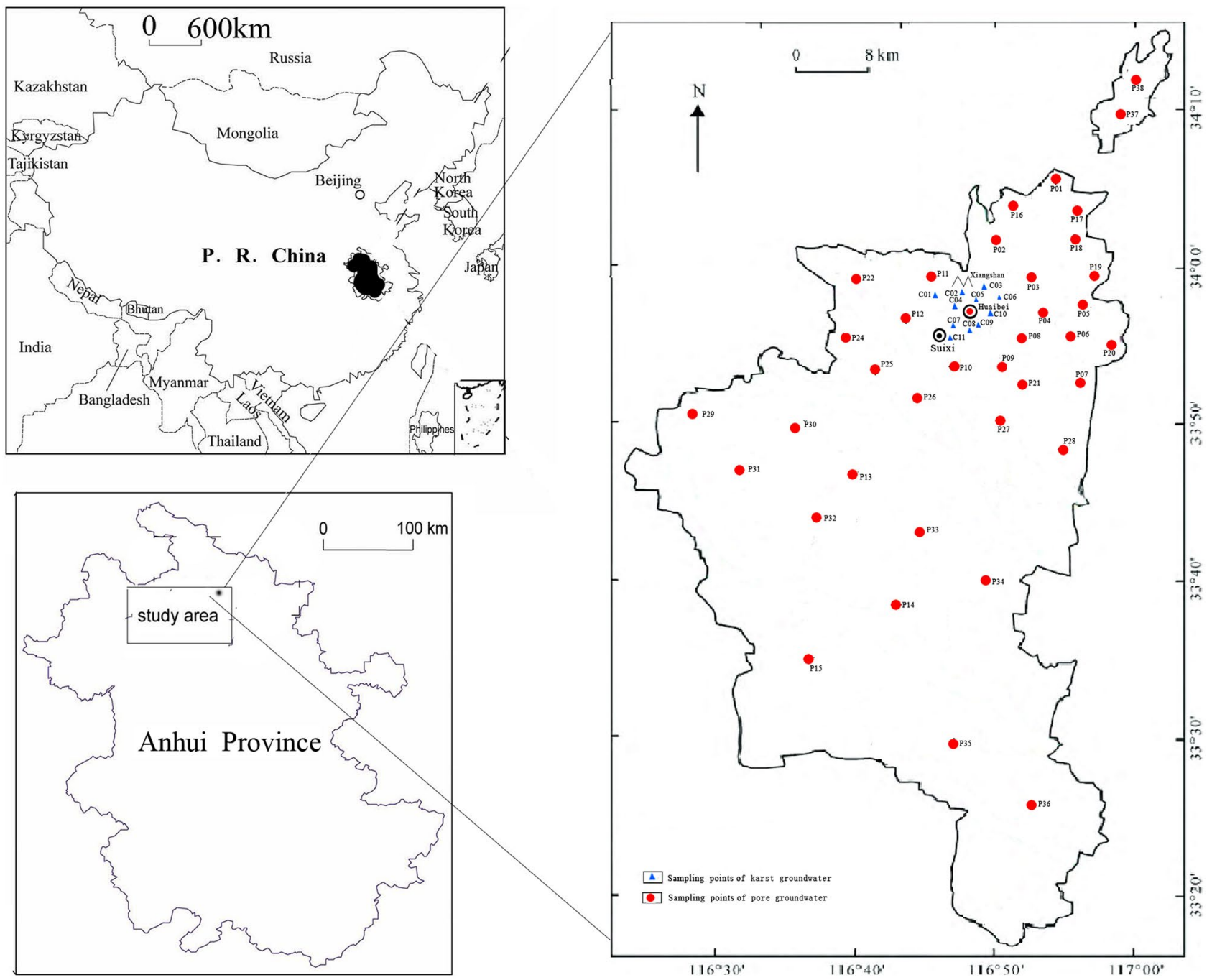

Figure 1. Location map and sampling points of study area (created with the software of Coreldraw X8).

Health risk assessment model. Health risk assessment (HRA) is an effective probabilistic approach which links water pollution with human health ${ }^{13,32}$. It can quantitatively describe the harm of environmental pollution to human environment. As fluoride has a direct impact on human health ${ }^{14}$, the health risk assessment of fluoride in groundwater can provide a baseline information for ensuring the safety of drinking water and sustainable utilization of water resources. The health risk assessment model recommended by the United States Environmental Protection Agency (USEPA) has been widely used and confirmed in the water quality assessment of drinking water ${ }^{7,33}$. In this study, the model is used to evaluate the health risk of fluoride in groundwater.

Fluoride in drinking water mainly enters the human body through drinking water intake and skin contact. Many studies show that the value of risk through skin contact is very small and can be ignored relative to drinking water intake $e^{1,13}$. Since drinking water is the main risk source of fluoride to human bodies ${ }^{11}$, only drinking water intake is considered in this study. Fluoride is a non-carcinogenic risk factor, the health risk assessment of fluoride content in groundwater in the study area is carried out by using the non-carcinogenic risk assessment risk model. The calculation formula is as follows:

$$
\begin{gathered}
I_{C D I}=\frac{C \cdot I R \cdot E F \cdot E D}{B W \cdot A T} \\
H I=\frac{I_{\mathrm{CDI}}}{R f D}
\end{gathered}
$$

The formula parameters for the calculation of $I_{C D I}$ values are described in Table 1 obtained from previous studies ${ }^{13,34-36}$. Although adults are considered in the area, special attention should be pay to the children and infants. The studied people are classified into three groups: infants (less than 2 years), children ( 2 to $<16$ years) and adults ( $\geq 16$ years).

Recommendations based on the standards of USEPA's health risk assessment, the threshold value of the noncarcinogenic risk index $(H I)$ is 1 . When $H I>1$, it indicates that the non-carcinogenic risk of the human body 


\begin{tabular}{|c|c|c|c|c|c|}
\hline Parameters & Unit & & Children & Adults & Literature \\
\hline C: Concentration of fluoride & $\mathrm{mg} / \mathrm{L}$ & Fluoride concentration in this study & & & \\
\hline IR: Ingestion rate of water (L/day) & L/day & 0.5 & 1.5 & 2.4 & 34 \\
\hline EF: Exposure frequency & day/year & 200 & 350 & 350 & 36 \\
\hline ED: exposure duration for risk assessment & year & 1 & 12 & 64 & 35 \\
\hline BW: Average body weight & $\mathrm{kg}$ & 6 & 20 & 65 & 35 \\
\hline AT: Averaging time & Day & 200 & 4200 & 22,400 & 13 \\
\hline$R f D$ : Oral reference dose & $\mathrm{mg} / \mathrm{kg}$ day & 0.06 & 0.06 & 0.06 & 13 \\
\hline
\end{tabular}

Table 1. Parameters employed for human health risk exposure assessment in groundwater.

\begin{tabular}{|c|c|c|c|c|c|c|c|c|c|c|c|c|}
\hline \multirow[b]{2}{*}{ Index } & \multicolumn{5}{|c|}{ Karst water } & \multicolumn{5}{|c|}{ Pore water } & \multirow[b]{2}{*}{$\begin{array}{l}\text { Chinese } \\
\text { standard }^{37}\end{array}$} & \multirow[b]{2}{*}{$\begin{array}{l}\text { WHO } \\
\text { Standard }\end{array}$} \\
\hline & Min & Max & Average & $\begin{array}{l}\text { Standard } \\
\text { deviation }\end{array}$ & $\begin{array}{l}\text { Coefficient of } \\
\text { variation }\end{array}$ & Min & Max & Average & $\begin{array}{l}\text { Standard } \\
\text { deviation }\end{array}$ & $\begin{array}{l}\text { Coefficient of } \\
\text { variation }\end{array}$ & & \\
\hline $\mathrm{pH}$ & 7.14 & 7.34 & 7.58 & 0.16 & 0.02 & 7.36 & 8.37 & 7.91 & 0.27 & 0.03 & $6.5-8.5$ & $6.5-8.5$ \\
\hline $\mathrm{Na}^{+}$ & 26.03 & 95.51 & 333.50 & 82.60 & 0.25 & 45.01 & 468.40 & 179.64 & \begin{tabular}{|l|}
101.27 \\
\end{tabular} & 0.56 & 200 & 200 \\
\hline $\mathrm{Ca}^{2+}$ & 16.31 & 110.35 & 130.80 & 32.44 & 0.25 & 6.31 & 198.00 & 62.73 & 60.30 & 0.96 & - & 75 \\
\hline $\mathrm{Mg}^{2+}$ & 17.89 & 36.85 & 56.36 & 13.68 & 0.24 & 33.42 & 196.69 & 71.41 & 38.79 & 0.54 & - & 75 \\
\hline $\mathrm{Cl}^{-}$ & 29.80 & 68.45 & 169.42 & 39.43 & 0.23 & 31.55 & 420.44 & 110.04 & 92.89 & 0.84 & 250 & 200 \\
\hline $\mathrm{SO}_{4}{ }^{2-}$ & 63.08 & 185.15 & 272.70 & 58.80 & 0.22 & 33.75 & \begin{tabular}{|l|}
1010.07 \\
\end{tabular} & 192.03 & 212.55 & 1.11 & 250 & 250 \\
\hline \begin{tabular}{|l|} 
TDS \\
\end{tabular} & 515.00 & 681.36 & 883.00 & 129.36 & 0.15 & 301.00 & 2791.19 & 890.76 & 527.89 & 0.59 & 1000 & 500 \\
\hline $\mathrm{NO}_{3}^{-}$ & 8.80 & 24.24 & 45.89 & 15.27 & 0.33 & 0.00 & 25.97 & 9.92 & 7.95 & 0.80 & 20 & 50 \\
\hline $\mathrm{F}^{-}$ & 0.35 & 0.62 & 0.90 & 0.21 & 0.23 & 0.42 & 3.65 & 1.14 & 0.66 & 0.58 & 1.0 & 1.5 \\
\hline
\end{tabular}

Table 2. Descriptive statistics for groundwater samples in Huaibei, China. Concentration of ions and TDS is $\mathrm{mg} / \mathrm{L}$.

exposed to the environment is large, and it poses a certain threat to the health of the human body; When $H I<1$, it indicates that the risk is small and is regarded as acceptable.

\section{Results and discussion}

Distribution characteristic of fluoride. Table 2 indicated the parameters of groundwater, the parameters are compared to national ${ }^{37}$ and international standards $s^{38}$. The concentration of fluoride in centralized groundwater sources and decentralized groundwater sources ranging from 0.35 to $0.90 \mathrm{mg} / \mathrm{L}$ and 0.42 to $3.65 \mathrm{mg} / \mathrm{L}$, with an average of 0.62 and $1.14 \mathrm{mg} / \mathrm{L}$, respectively. The average concentration of fluoride in decentralized groundwater sources is higher than that of centralized groundwater sources. As shown in Fig. 2, the concentration of fluoride in centralized groundwater is less than the drinking water quality standard of fluoride, while 9 of 38 decentralized groundwater samples exceeded the drinking water quality standard of fluoride set by WHO, accounting for $23.68 \%$.

There is no obvious regularity in the horizontal distribution of fluoride content (Figs. 2, 3), and the content is small in the northern Xiangshan karst area. The concentration of fluoride in groundwater increases from north to south, and the vertical distribution of fluoride in groundwater decreases with the increase of well depth (Fig. 4), which is closely related to the depth of water intake layer. The concentration of fluoride in shallow groundwater is higher than that in deep groundwater. Since the groundwater is the main source of industrial and agricultural production, it is necessary to evaluate the human health risk of groundwater in the study area.

Sources of fluorine in groundwater. The enrichment of fluoride in groundwater is mainly related to the source of fluorine in rock and soil. Various fluoride minerals, including kaolinite, montmorillonite and hydromica, mica, apatite, tourmaline and hornblende are found in the aquifer formation of Huaibei ${ }^{39}$. Fluoride in fluorine minerals could be released with the rock-water interactions and lead to the increasing of fluoride in groundwater. The continuous dissolution of fluorine-containing minerals is the main resource of the enrichment of fluoride in groundwater, but its concentration variation also affected by many factors such as climate, topography and geology, lithologic structure, groundwater flow and environmental media. The shallow water is mainly vertical leaching of fluorine in vadose zone and leaching hydrolysis of fluorine in aquifer. The migration and enrichment of fluoride by horizontal runoff is relatively enhanced for the weakening of vertical alternation in deep water, which increases the fluoride content in aquifer. Meanwhile, drought climate and alkaline environment will lead to the increasing of fluoride content in groundwater. Some studies shown that the concentrated 


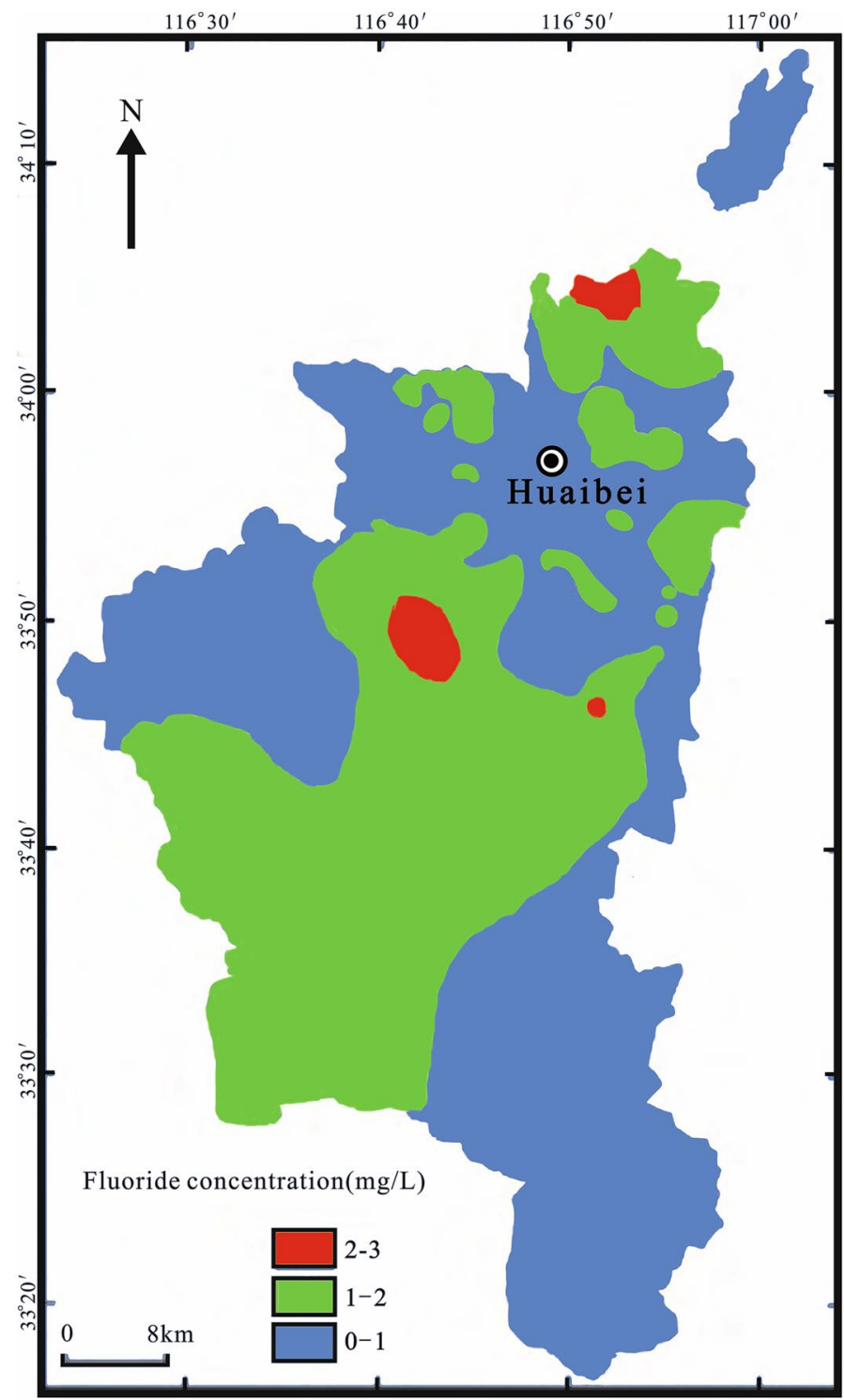

Figure 2. Map of fluoride concentrations in groundwater of study area (created with the software of ArcGIS desktop 10.7).

distribution area of high fluoride in groundwater is consistent with the high fluorine waste discharge sites such as coal mines and power plants ${ }^{28}$.

Mutual relationships between fluoride and other ions. Correlation coefficients have been shown to be successful in assessing strength and direction-Linear relationship between fluoride and other ions. Many studies shown that $\mathrm{pH}$ value plays a decisive role in the occurrence of fluorine in water ${ }^{9,40}$, and alkaline water is more conducive to the dissolution of fluorine-containing minerals. According to Fig. 5A, the positive correlation between $\mathrm{pH}$ value and $\mathrm{F}^{-}$in unconsolidated aquifer. The $\mathrm{pH}$ value of groundwater plays a decisive role in the occurrence of fluorine. In neutral and alkalescent groundwater, there are many forms of fluorine, such as $\mathrm{F}^{-}$, $\mathrm{CaF}^{+}, \mathrm{MgF}^{+}$et al. With the increasing of $\mathrm{pH}$ value, soluble $\mathrm{F}^{-}$occupies the main position. The activity of $\mathrm{Ca}^{2+}$ reduces in alkaline and alkalescent groundwater, which weakens the role of $\mathrm{F}^{-}$aggregation ability, and is conducive to the enrichment of $\mathrm{F}^{-}$in groundwater. There is the following equilibrium relationship in groundwater:

$$
\begin{gathered}
\mathrm{Ca}(\mathrm{OH})_{2} \leftrightharpoons \mathrm{Ca}^{2+}+2 \mathrm{OH}^{-} \\
\mathrm{Ca}^{2+}+2 \mathrm{~F}^{-} \leftrightharpoons \mathrm{CaF}_{2}
\end{gathered}
$$

When the groundwater is alkaline or slightly alkaline, the concentration of $\mathrm{OH}^{-}$is higher, and the equilibrium of Eq. (3) moves to the left, resulting in Eq. (4) also moves to the left, so the concentration of $\mathrm{F}^{-}$increases. Alkaline 


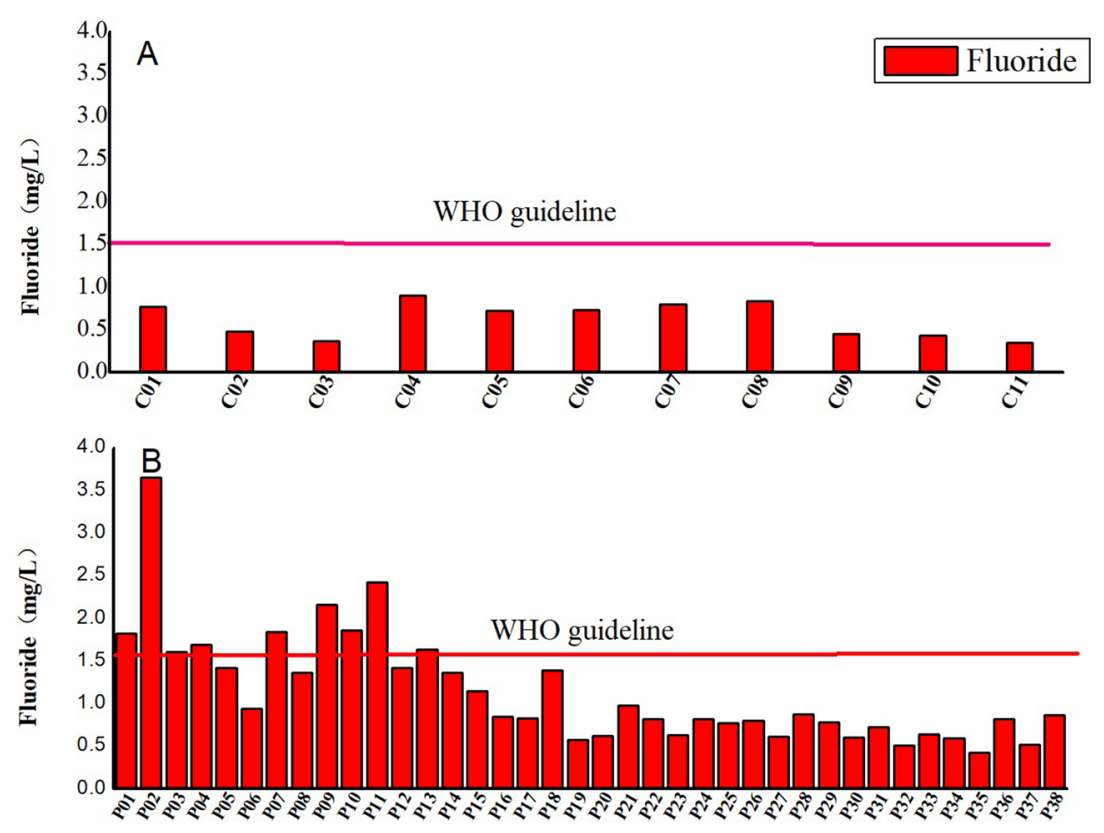

Figure 3. Comparison of mean fluoride concentrations in groundwater with WHO guideline of fluoride in drinking water: (A) Centralized groundwater sources. (B) Decentralized groundwater sources.

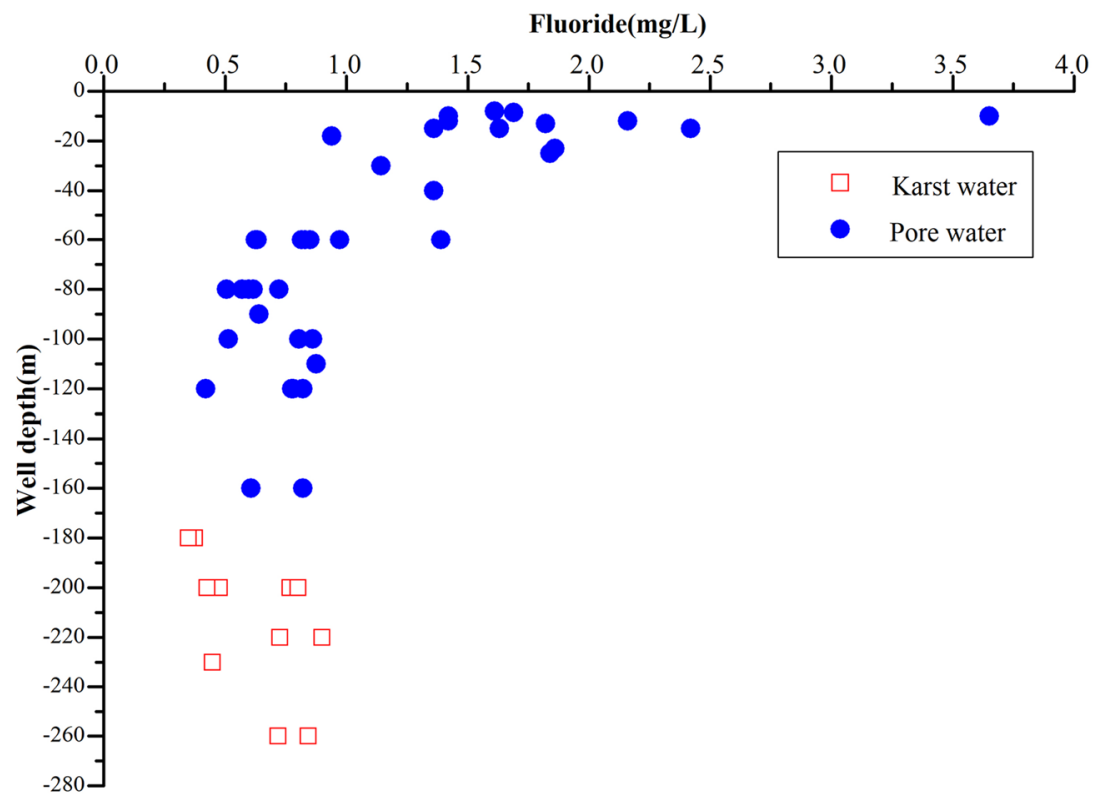

Figure 4. Relationship between fluoride concentrations and well depth.

and slightly alkaline water is conducive to the dissolution of fluorinated minerals $\left(\mathrm{CaF}_{2}\right)$, so the concentration of $\mathrm{F}^{-}$increases with the increase of $\mathrm{pH}$ value. Therefore, alkaline and alkalescent water is favorable for $\mathrm{F}^{-}$enrichment. The $\mathrm{pH}$ value of groundwater in Huaibei Plain is generally between 7.14 and $8.67^{28}$, which is alkaline and alkalescent, which is favorable for the enrichment of $\mathrm{F}^{-}$. Furthermore, $\mathrm{F}^{-}$adsorbed on the clay surface is easily replaced by $\mathrm{OH}^{-}$which leads to the enrichment of $\mathrm{F}^{-}$in alkaline environment. $\mathrm{F}^{-}$can be replaced with hydroxyl $\left(\mathrm{OH}^{-}\right)$ion and mobilized from micas (such as biotite and muscovite) and clay minerals into groundwater through ion exchange due to the similar ionic radii of $\mathrm{OH}^{-}$and $\mathrm{F}^{-}$at alkaline condition ${ }^{21}$.

There is a negative correlation between $\mathrm{F}^{-}$content and $\mathrm{Ca}^{2+}$ content (Fig. 5B). The content of fluoride decreases with the increasing of $\mathrm{Ca}^{2+}$ content, which may be explained by the interaction between calcium ion and fluorine ion to with the formation of insoluble apatite $\left(\mathrm{Ca}_{5}\left(\mathrm{PO}_{4}\right)_{3} \mathrm{~F}\right)$, fluorite $\left(\mathrm{CaF}_{2}\right)$ and other solid materials ${ }^{41}$. Occurrence of the elevated fluoride concentrations, $\mathrm{Ca}^{2+}$ is low obviously due to the fluoride dissolution balance ${ }^{42}$. For 

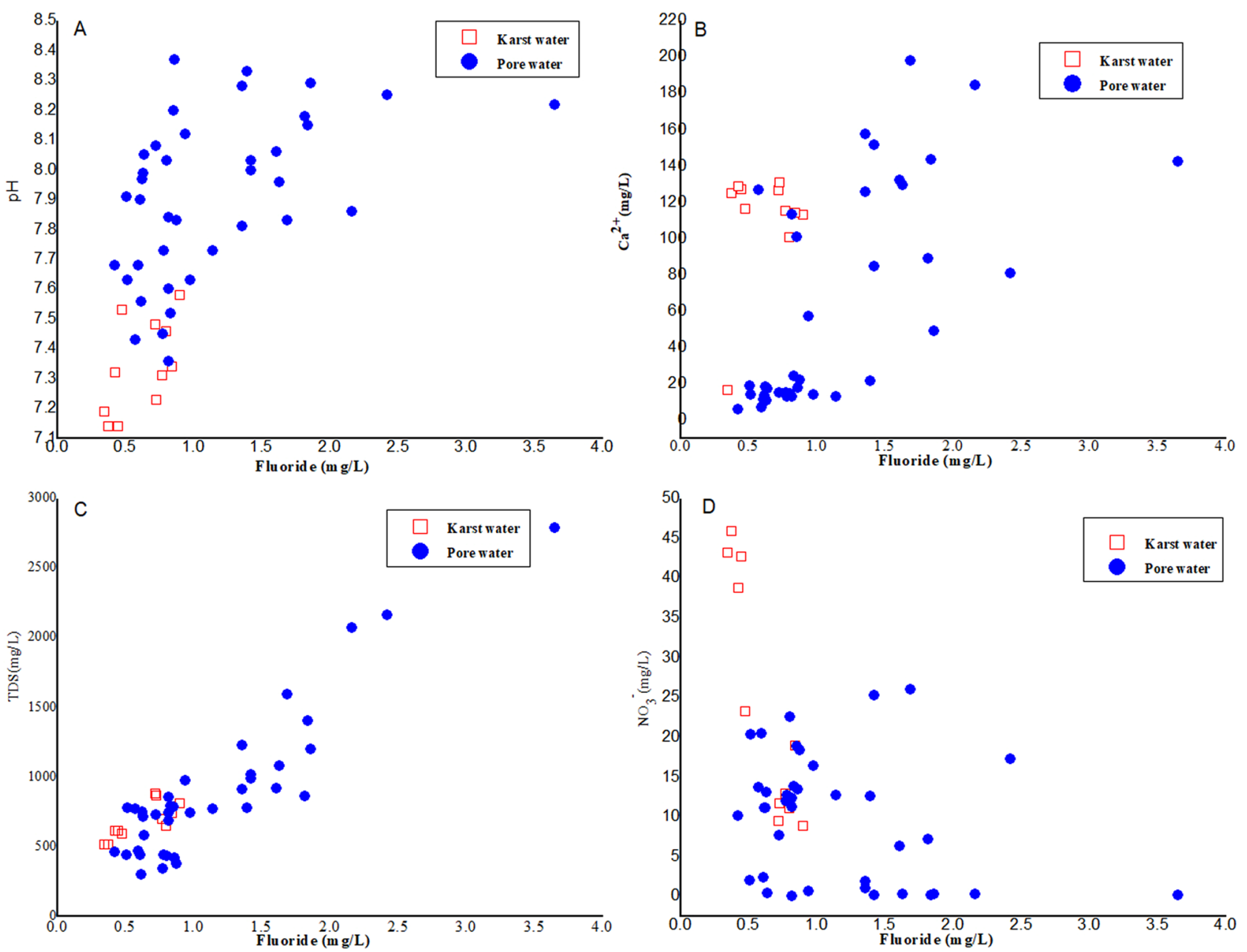

Figure 5. Relationship between the fluoride concentration with major ions in groundwater sources of Huaibei: (A) $\mathrm{pH},(\mathbf{B}) \mathrm{Ca}^{2+}$, (C) TDS, (D) $\mathrm{NO}_{3}^{-}$.

the elevated concentration of $\mathrm{Ca}^{2+}$ in the centralized water source samples from karst aquifer, $\mathrm{F}^{-}$content is lower than that in decentralized groundwater sources.

According to Fig. 5C, there is a positive correlation between $\mathrm{F}^{-}$content and TDS in water, indicating that $\mathrm{F}^{-}$content in groundwater increases with the increasing of TDS. Evaporation will lead to the gradual concentration of groundwater and the increase of TDS. Minerals with low solubility will reach saturation and precipitate easily. Fluoride in groundwater is mainly comes from water-soluble fluorine ion in the study area, which accumulates continuously with the evaporation of groundwater. The content of TDS increases, the total amount of ions in water increases, which will promote the dissolution of $\mathrm{F}^{-}$into groundwater. The high intensity of annual evaporation from surface water and evapotranspiration from land surfaces are found in the selected area, and the fluoride accumulates with the amount of groundwater, resulting in the higher fluoride content in the shallower well depth.

It has been reported that $\mathrm{NO}_{3}{ }^{-}$in groundwater is mainly originated from human activities, For example, coal mines, power plants and other high fluorine waste emissions ${ }^{28}$. $\mathrm{NO}_{3}{ }^{-}$contamination in groundwater may be the result of agricultural factors such as fertilizers or animal wastes ${ }^{42}$. The correlation between $\mathrm{F}^{-}$and $\mathrm{NO}_{3}{ }^{-}$can reflect the influence of human activities on $\mathrm{F}^{-}$in groundwater. According to Fig. 5D, the poor correlation between $\mathrm{F}^{-}$and $\mathrm{NO}_{3}{ }^{-}$in groundwater indicating that the enrichment of $\mathrm{F}^{-}$in groundwater is mainly derived from natural sources.

Health risk assessment of $\mathbf{F}$ exposure in groundwater. The $H I$ values of fluoride in centralized and decentralized groundwater sources are depicted in Fig. 6. Since the concentration of fluoride in centralized groundwater source is lower than that in decentralized one, the corresponding health risk value is also lower than that in decentralized water source. In centralized groundwater sources, The HI values of fluoride ranged from 0.8872 to 2.2787 (mean 1.5741) and from 0.4563 to 1.1719 (mean 0.8096), from 0.2246 to 0.5769 (mean 0.3946) for infants, children, and adults, respectively indicating that fluoride may cause deleterious health impacts in the order of: infants > children > adults. Whereas for fluoride, $H I$ values in $81.82 \%, 36.36 \%$ and $0 \%$ of studied locations are above the acceptable USEPA limit of 1 for infants, children, and adults, respectively. In decentralized groundwater sources, $H I$ values for infants, children, and adults varied from 1.0646 to 9.2517 (mean 2.8928), from 0.5475 to 4.7580 (mean 1.4877), and from 0.2695 to 2.3424 (mean 0.7324 ), respectively. 


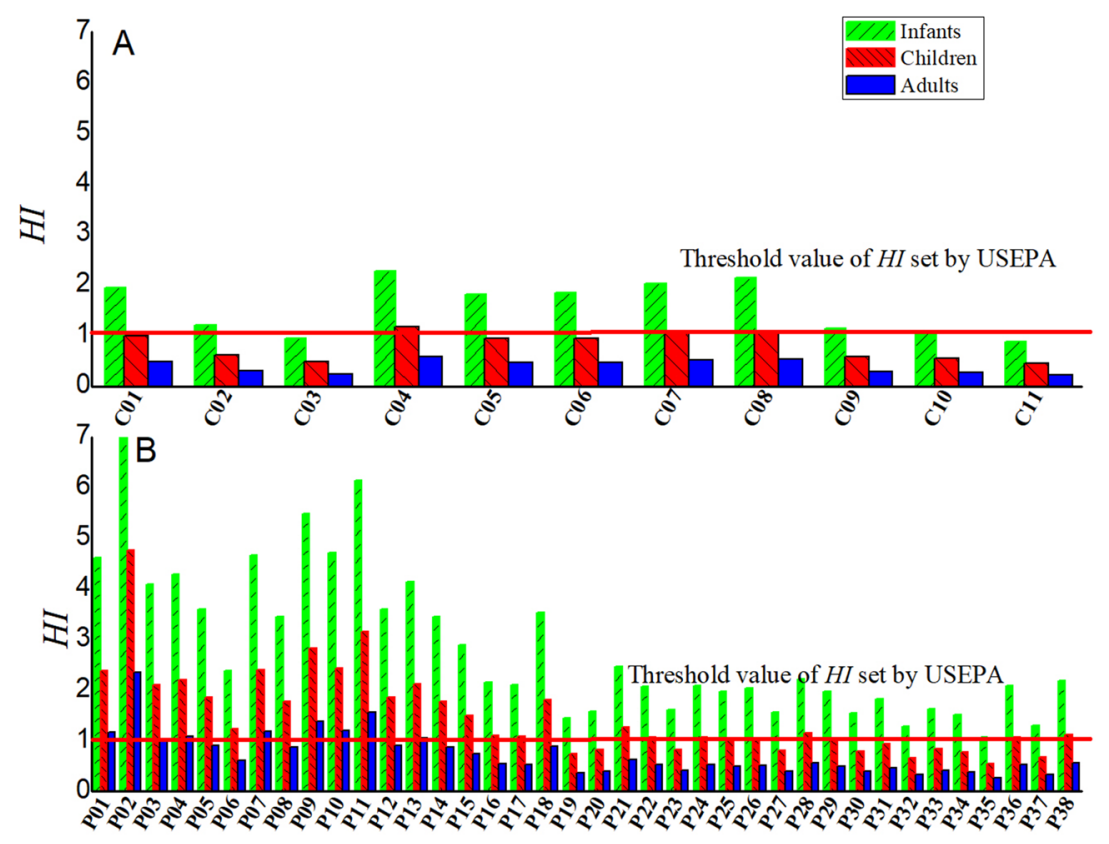

Figure 6. Statistical graph of fluoride noncarcinogenic risk for oral pathway: (A) centralized groundwater sources. (B) Decentralized groundwater sources.

$\mathrm{HI}$ estimated for groundwater in $100 \%, 71.05 \%$ and $23.68 \%$ cases are found to be above the safety limit of 1 for infants, children, and adults, respectively. The results means there is a potential risk of developing non cancer health risks in infants, children and adults through drinking water in most locations in the study area. The $H I$ values of fluoride for the three exposed groups varied in the same order: infants $>$ children $>$ adults.

Narsimha Adimallaa, $b$ and Hui Qian ${ }^{43}$ investigated assessment of human health risk associated with fluoride contamination in groundwater of Telangana and found children are at highly prone to health risk when compared to adults. In another study, Indrani Mukherjeea and Umesh Kumar Singh ${ }^{44}$ evaluated the health risks to the residents of Birbhum district, India associated with groundwater fluoride exposure. Infants and children are more susceptible to the non-carcinogenic health hazards of fluoride than adults. Similar results are also found in some studies ${ }^{6,7,45}$. It has been reported that infants and children are more sensitive receptors and face higher health risks than adults. For the lower body weight, per unit weight are more sensitive to fluoride pollution for children than that of adults, and long term exposure of groundwater with high fluorine content through ingestion exposure route ${ }^{46}$. The developing infants and children are more vulnerable to fluoride neurotoxicity ${ }^{15}$. It is necessary to carry out groundwater fluoride health risk management to avoid or reduce the impact of groundwater fluoride on the health of infants and children.

It is suggested that for low-risk areas, protection measures should be taken to avoid fluoride pollution in groundwater caused by human activities. For high-risk areas, more efforts should be made to control fluoride in groundwater, and monitoring of dental caries in children should be carried out to prevent the prevalence of dental caries. According to the actual situation, measures should be taken to reduce the fluoride concentration in groundwater, such as precipitation method, adsorption method. Mining deep wells with low fluoride, selecting surface water suitable for drinking to find new water sources, perfecting and improving centralized water supply measures, to ensure the safety of drinking water.

Uncertainty analysis. Water environmental health risk assessment includes the risk of toxic pollutants to human health through direct contact, ingestion of food, drinking water and respiration. This study only calculated the harm of drinking water intake to human health, without considering other toxic substances and exposure routes. Therefore, the actual health risk level of fluoride pollution in groundwater should be greater than the risk value of this study.

In the health risk assessment of groundwater fluoride, the model parameters are mainly the existing parameters in elder studies, only the influence of fluoride concentration is considered. However, different occupation, gender and consumption habits will lead to differences in health risk assessment parameters. Therefore, it is suggested to carry out basic research on health risk assessment, provide parameters suitable for the health risk assessment of population in the study area, improve the accuracy of groundwater health risk assessment, and provide scientific basis for the safety management of regional groundwater quality. This study on the health risk of fluoride in groundwater in Huaibei is preliminary and will be further improved in the future work. 


\section{Conclusions}

The concentration of fluoride selected from centralized groundwater sources and decentralized groundwater sources are ranged from 0.35 to $0.90 \mathrm{mg} / \mathrm{L}$ and 0.42 to $3.65 \mathrm{mg} / \mathrm{L}$, with an average of 0.62 and 1.42 , respectively. The average concentration of fluoride in the decentralized groundwater source is higher than that of centralized groundwater sources. And the vertical distribution of fluoride in groundwater tend to decreases with the increase of well depth. Groundwater fluoride mainly derived from fluoride-rich minerals by the effect of chemical weathering, rock-water interaction, ion-exchange and evapotranspiration. High fluoride concentrations are associated with weakly alkaline conditions, moderate total dissolved solids. Among them, calcium ions are regarded as the dominant ions for association of fluoride in groundwater. The distribution attributed to different geological conditions, and also related to environmental conditions and high fluoride waste discharge.

In centralized groundwater sources, The $H I$ values of fluoride ranged from 0.8872 to 2.2787 (mean 1.5741) and from 0.4563 to 1.1719 (mean 0.8096 ), from 0.2246 to 0.5769 (mean 0.3946 ) for infants, children, and adults, respectively. While in centralized and decentralized groundwater sources, $H I$ values for infants, children, and adults varied from 1.0646 to 9.2517 (mean 2.8928), from 0.5475 to 4.7580 (mean 1.4877), and from 0.2695 to 2.3424 (mean 0.7324 ), respectively. Results indicated that the $H I$ values for studied groups are in the same order: infants $>$ children $>$ adults. The infants and children are more prone to risk of fluoride in the groundwater compared with adults. Measures should be taken to ensure the safety of drinking water from fluoride contamination.

Received: 5 January 2021; Accepted: 31 March 2021

Published online: 16 April 2021

\section{References}

1. Dehghani, M. H., Zarei, A., Yousefi, M., Baghal Asghari, F. \& Haghighat, G. A. Fluoride contamination in groundwater resources in the southern Iran and its related human health risks. Desalin. Water Treat. 153, 95-104. https://doi.org/10.5004/dwt.2019.23993 (2019).

2. Bodrud-Doza, M. et al. Groundwater quality and human health risk assessment for safe and sustainable water supply of Dhaka City dwellers in Bangladesh. Groundw. Sustain. Dev. https://doi.org/10.1016/j.gsd.2020.100374 (2020).

3. Yousefi, M. et al. Northwest of Iran as an endemic area in terms of fluoride contamination: A case study on the correlation of fluoride concentration with physicochemical characteristics of groundwater sources in Showt. Desalin. Water Treat. 155, 183-189. https://doi.org/10.5004/dwt.2019.23932 (2019).

4. Chen, Q. et al. Geochemical process of groundwater fluoride evolution along global coastal plains: Evidence from the comparison in seawater intrusion area and soil salinization area. Chem. Geol. https://doi.org/10.1016/j.chemgeo.2020.119779 (2020).

5. Ghadewpoori, M., Jahed Kharxiki, G. R., Dehghani, M. H., Shams, M. \& Zarei, A. Determination of fluoride in bottled water sold in Tehran market. Am. Eur. J. Agric. Environ. Sci. 6(3), 324-327 (2009).

6. Qasemi, M. et al. Spatial distribution of fluoride and nitrate in groundwater and its associated human health risk assessment in residents living in Western Khorasan Razavi, Iran. Desalin. Water Treat. 170, 176-186. https://doi.org/10.5004/dwt.2019.24691 (2019).

7. Toolabi, A., Bonyadi, Z., Paydar, M., Najafpoor, A. A. \& Ramavandi, B. Spatial distribution, occurrence, and health risk assessment of nitrate, fluoride, and arsenic in Bam groundwater resource, Iran. Groundw. Sustain. Dev. https://doi.org/10.1016/j.gsd.2020. 100543 (2021).

8. Rashid, A. et al. Geochemical modeling, source apportionment, health risk exposure and control of higher fluoride in groundwater of sub-district Dargai, Pakistan. Chemosphere 243, 125409. https://doi.org/10.1016/j.chemosphere.2019.125409 (2020).

9. Narsimha, A. Assessment and mechanism of fluoride enrichment in groundwater from the hard rock terrain: A multivariate statistical approach. Geochem. Int. 58, 456-471. https://doi.org/10.1134/s0016702920040060 (2020).

10. Karunanidhi, D., Aravinthasamy, P., Kumar, D., Subramani, T. \& Roy, P. D. Sobol sensitivity approach for the appraisal of geomedical health risks associated with oral intake and dermal pathways of groundwater fluoride in a semi-arid region of south India. Ecotoxicol. Environ. Saf. 194, 110438. https://doi.org/10.1016/j.ecoenv.2020.110438 (2020).

11. Sawangjang, B., Hashimoto, T., Wongrueng, A., Wattanachira, S. \& Takizawa, S. Assessment of fluoride intake from groundwater and intake reduction from delivering bottled water in Chiang Mai Province, Thailand. Heliyon 5, e02391. https://doi.org/10.1016/j. heliyon.2019.e02391 (2019).

12. Hossain, M. \& Patra, P. K. Hydrogeochemical characterisation and health hazards of fluoride enriched groundwater in diverse aquifer types. Environ. Pollut. 258, 113646. https://doi.org/10.1016/j.envpol.2019.113646 (2020).

13. Mukherjee, I., Singh, U. K. \& Patra, P. K. Exploring a multi-exposure-pathway approach to assess human health risk associated with groundwater fluoride exposure in the semi-arid region of east India. Chemosphere 233, 164-173. https://doi.org/10.1016/j. chemosphere.2019.05.278 (2019).

14. Yuan, L. et al. Health risk in children to fluoride exposure in a typical endemic fluorosis area on Loess Plateau, north China, in the last decade. Chemosphere 243, 125451. https://doi.org/10.1016/j.chemosphere.2019.125451 (2020).

15. Zhang, L. et al. Spatial distribution of fluoride in drinking water and health risk assessment of children in typical fluorosis areas in north China. Chemosphere 239, 124811. https://doi.org/10.1016/j.chemosphere.2019.124811 (2020).

16. Liu, Y., Jin, M., Ma, B. \& Wang, J. Distribution and migration mechanism of fluoride in groundwater in the Manas River Basin, Northwest China. Hydrogeol. J. 26, 1527-1546. https://doi.org/10.1007/s10040-018-1780-8 (2018).

17. USEPA. 2018 Edition of the Drinking Water Standards and Health Advisories. Office of Water U.S. Environmental Protection Agency, Washington, DC EPA 822-F-18-001. (2018).

18. Enalou, H. B., Moore, F., Keshavarzi, B. \& Zarei, M. Source apportionment and health risk assessment of fluoride in water resources, south of Fars province, Iran: Stable isotopes $(\delta 18 \mathrm{O}$ and $\delta \mathrm{D})$ and geochemical modeling approaches. Appl. Geochem. 98, 197-205. https://doi.org/10.1016/j.apgeochem.2018.09.019 (2018).

19. WHO. Guidelines for Driking-Water Quality 4th edn. (World Health Organization, 2011).

20. Abiye, T., Bybee, G. \& Leshomo, J. Fluoride concentrations in the arid Namaqualand and the Waterberg groundwater, South Africa: Understanding the controls of mobilization through hydrogeochemical and environmental isotopic approaches. Groundw. Sustain. Dev. 6, 112-120. https://doi.org/10.1016/j.gsd.2017.12.004 (2018).

21. Mukherjee, I. \& Singh, U. K. Fluoride abundance and their release mechanisms in groundwater along with associated human health risks in a geologically heterogeneous semi-arid region of east India. Microchem. J. 152, 104304. https://doi.org/10.1016/j. microc.2019.104304 (2020).

22. Reddy, B. M. V Sunitha Geochemical and health risk assessment of fluoride and nitrate toxicity in semi-arid region of Anantapur District, South India. Environ. Chem. Ecotoxicol. 2, 150-161. https://doi.org/10.1016/j.enceco.2020.09.002 (2020). 
23. Chen, Q. et al. Geochemical process of groundwater fluoride evolution along global coastal plains: Evidence from the comparison in seawater intrusion area and soil salinization area. Chem. Geol. 552, 119779. https://doi.org/10.1016/j.chemgeo.2020.119779 (2020).

24. Yadav, K. K. et al. Fluoride contamination, health problems and remediation methods in Asian groundwater: A comprehensive review. Ecotoxicol. Environ. Saf. 182, 109362. https://doi.org/10.1016/j.ecoenv.2019.06.045 (2019).

25. Wang, M. et al. Distribution, health risk assessment, and anthropogenic sources of fluoride in farmland soils in phosphate industrial area, southwest China. Environ. Pollut. 249, 423-433. https://doi.org/10.1016/j.envpol.2019.03.044 (2019).

26. Bhattacharya, P. et al. Health risk assessment of co-occurrence of toxic fluoride and arsenic in groundwater of Dharmanagar region, North Tripura (India). Groundw. Sustain. Dev. https://doi.org/10.1016/j.gsd.2020.100430 (2020).

27. Hu, Y., Zhongbing, D. \& Guijian, L. Characterization and quality of groundwater in Huaibei, China. Fresenius Environ. Bull. 26(4), 2541-2549 (2017).

28. Hu, Y., Xia, C., Dong, Z. \& Liu, G. Geochemical characterization of fluoride in the groundwater of the Huaibei Plain, China. Anal. Lett. 50, 889-903. https://doi.org/10.1080/00032719.2016.1199027 (2016).

29. Hu, Y., Fuha, Z., Zhiyuan, N., Zhongbing, D. \& Guijian, L. Hydrochemical characteristics of groundwater in centralized drinking water sources and its quality assessment in northern Anhui province. J. Univ. Sci. Technol. 44(11), 913-920, 925 (2015).

30. Hu, Y. et al. Groundwater quality at the Huaibei Coalfield, China. Anal. Lett. 48, 1654-1669. https://doi.org/10.1080/00032719. 2014.991961 (2015).

31. Qian, J. et al. Hydrochemical processes and evolution of karst groundwater in the northeastern Huaibei Plain, China. Hydrogeol. J. 26, 1721-1729. https://doi.org/10.1007/s10040-018-1805-3 (2018).

32. Yadav, K. K. et al. Human health risk assessment: Study of a population exposed to fluoride through groundwater of Agra city, India. Regul. Toxicol. Pharmacol. 106, 68-80. https://doi.org/10.1016/j.yrtph.2019.04.013 (2019).

33. Soleimani, H. et al. Groundwater quality evaluation and risk assessment of nitrate using monte carlo simulation and sensitivity analysis in rural areas of Divandarreh County, Kurdistan province, Iran. Int. J. Environ. Anal. Chem. https://doi.org/10.1080/03067 319.2020.1751147 (2020)

34. Mondal, N. K., Pal, K. C. \& Kabi, S. Prevalence and severity of dental fluorosis in relation to fluoride in ground water in the villages of Birbhum district, West Bengal, India. Environmentalist 32, 70-84 (2012).

35. Narsimha, A. \& Rajitha, S. Spatial distribution and seasonal variation in fluoride enrichment in groundwater and its associated human health risk assessment in Telangana State, South India. Hum. Ecol. Risk Assess. Int. J. 24, 2119-2132. https://doi.org/10. 1080/10807039.2018.1438176 (2018).

36. Chavoshi, E. et al. Health risk assessment of fluoride exposure in soil, plants, and water at Isfahan, Iran. Human Ecol. Risk Assess. Int. J. 17, 414-430. https://doi.org/10.1080/10807039.2011.552397 (2011).

37. SACRIFICE. Chinese standard for groundwater quality (GB/T14848-2017) (2017)

38. WH Organization. Guidelines for Drinking-Water Quality 4th edn. (W. H. Organization, 2011).

39. Huai-xue, X. I. N. G. et al. Spatial distribution characteristics and origin of fluorine in groundwater of Huaibei City, Anhui Province. Acta Geosci. Sin. https://doi.org/10.3975/cagsb.2014.02.06 (2014).

40. Liu, J., Peng, Y., Li, C., Gao, Z. \& Chen, S. A characterization of groundwater fluoride, influencing factors and risk to human health in the southwest plain of Shandong Province, North China. Ecotoxicol. Environ. Saf. 207, 111512. https://doi.org/10.1016/j.ecoenv. $2020.111512(2021)$.

41. Yan, J., Chen, J., Zhang, W. \& Ma, F. Determining fluoride distribution and influencing factors in groundwater in Songyuan, Northeast China, using hydrochemical and isotopic methods. J. Geochem. Explor. 217, 106605. https://doi.org/10.1016/j.gexplo. $2020.106605(2020)$.

42. Li, D., Gao, X., Wang, Y. \& Luo, W. Diverse mechanisms drive fluoride enrichment in groundwater in two neighboring sites in northern China. Environ. Pollut. 237, 430-441. https://doi.org/10.1016/j.envpol.2018.02.072 (2018).

43. Adimalla, N. \& Qian, H. Spatial distribution and health risk assessment of fluoride contamination in groundwater of Telangana: A state-of-the-art. Geochemistry https://doi.org/10.1016/j.chemer.2019.125548 (2020).

44. Mukherjee, I. \& Singh, U. K. Fluoride abundance and their release mechanisms in groundwater along with associated human health risks in a geologically heterogeneous semi-arid region of east India. Microchem. J. https://doi.org/10.1016/j.microc.2019. 104304 (2020).

45. Yousefi, M., Ghoochani, M. \& Hossein Mahvi, A. Health risk assessment to fluoride in drinking water of rural residents living in the Poldasht city, Northwest of Iran. Ecotoxicol. Environ. Saf. 148, 426-430. https://doi.org/10.1016/j.ecoenv.2017.10.057 (2018).

46. Adimalla, N. \& Qian, H. Spatial distribution and health risk assessment of fluoride contamination in groundwater of Telangana: A state-of-the-art. Geochemistry https://doi.org/10.1016/j.chemer.2019.125548 (2019).

\section{Acknowledgements}

This work was financially supported by the Key Program for Science and Technology Development of Anhui Province (no. 1908085MD113), the Postdoctoral Science Foundation of China (no. 2016M602037). We acknowledge editors and reviewers for polishing the language of the paper and for in-depth discussion.

\section{Author contributions}

Y.H.: Data curation, Writing - original draft. M.Y.: Writing-review \& editing. G.L.: Investigation. Z.D.: Data curation

\section{Competing interests}

The authors declare no competing interests.

\section{Additional information}

Correspondence and requests for materials should be addressed to G.L.

Reprints and permissions information is available at www.nature.com/reprints.

Publisher's note Springer Nature remains neutral with regard to jurisdictional claims in published maps and institutional affiliations. 
(c) (i) Open Access This article is licensed under a Creative Commons Attribution 4.0 International cc) License, which permits use, sharing, adaptation, distribution and reproduction in any medium or format, as long as you give appropriate credit to the original author(s) and the source, provide a link to the Creative Commons licence, and indicate if changes were made. The images or other third party material in this article are included in the article's Creative Commons licence, unless indicated otherwise in a credit line to the material. If material is not included in the article's Creative Commons licence and your intended use is not permitted by statutory regulation or exceeds the permitted use, you will need to obtain permission directly from the copyright holder. To view a copy of this licence, visit http://creativecommons.org/licenses/by/4.0/.

(C) The Author(s) 2021 